\section{Physiological performance of Garcinia gardneriana (Planch. \& Triana) Zappi: a species with recalcitrant and dormant seeds}

\author{
Willian Goudinho Viana ${ }^{1}$ (D) Ana Paula Lando ${ }^{1}$ (D), Rosa Angelica da Silva ${ }^{1}$ (D), \\ Cláudia Dias da $\operatorname{Costa}^{1}$ (D), Pedro Henrique Mastriane Vieira ${ }^{1}$ (D), Neusa \\ Steiner ${ }^{1 *}$ iD
}

ABSTRACT: Garcinia gardneriana (Planch. \& Triana) Zappi is a native species widely distributed in Brazil. It has ornamental features, edible fruits, and its leaves have medicinal properties; however, its potential has not been explored. The aim of this study was to evaluate seed physiological performance due to dormancy, desiccation and storage tolerance. Only decoated seeds germinated. Seeds had an initial water content of $1.07 \mathrm{~g} \mathrm{H}_{2} \mathrm{O}^{-1} \mathrm{dw}$ and final germination of $95 \%$. Both desiccation to $0.67 \mathrm{~g} \mathrm{H}_{2} \mathrm{O} . \mathrm{g}^{-1} \mathrm{dw}$ and storage at 25 을 for ninety days resulted in decreased germination, 43 and $41 \%$, respectively. Desiccation below $0.25 \mathrm{~g} \mathrm{H}_{2} \mathrm{O} \cdot \mathrm{g}^{-1} \mathrm{dw}$ and storage for ninety days at $5 \stackrel{\circ}{ } \mathrm{C}$ were lethal. A rapid decrease in enzymic protection by superoxide dismutase and ascorbate peroxidase was correlated to desiccation sensitivity. Total polyamines content was higher in fresh seeds and markedly decreased with desiccation. The decrease in enzyme activity and polyamines content seems to be associated with seed viability loss. In sum, G. gardneriana seeds have a low tolerance to desiccation and are sensitive to chilling. Therefore, the seeds can be categorized as recalcitrant and dormant, a rare combination in terms of seed biology.

Index terms: antioxidant enzymes, desiccation tolerance, physical dormancy, polyamines, germination.

Desempenho fisiológico de sementes de Garcinia gardneriana (Planch. \& Triana) Zappi: uma espécie com sementes recalcitrantes e dormentes

RESUMO: Garcinia gardneriana (Planch. \& Triana) Zappi é uma espécie nativa amplamente distribuída no Brasil. Tem características ornamentais, frutos comestíveis e folhas com propriedades medicinais. No entanto, seu potencial ainda não é explorado. O objetivo deste estudo foi avaliar o desempenho fisiológico das sementes devido à dormência, dessecação e tolerância ao armazenamento. Apenas sementes sem tegumento germinaram. As sementes apresentaram um conteúdo inicial de água de $1,07 \mathrm{~g} \mathrm{H}_{2} \mathrm{O}^{-1} \mathrm{dw}$ e germinação final de $95 \%$. Ambos, dessecação para $0,67 \mathrm{~g} \mathrm{H}_{2} \mathrm{O} . \mathrm{g}^{-1} \mathrm{dw}$ e armazenamento a 25 ㄷ $\mathrm{C}$ por noventa dias, resultaram em decréscimo na germinação, 43 e $41 \%$, respectivamente. Dessecação abaixo de $0,25 \mathrm{~g} \mathrm{H}_{2} \mathrm{O} \cdot \mathrm{g}^{-1}$ $\mathrm{dw}$ e armazenamento por noventa dias a 5 C foram letais. Uma rápida diminuição na proteção enzimática pela superóxido dismutase e ascorbato peroxidase foi correlacionada à intolerância à dessecação. $O$ conteúdo total de poliaminas foi maior nas sementes frescas e diminuiu com a dessecação. A diminuição da atividade enzimática e do conteúdo de poliaminas está associada à perda de viabilidade de sementes. Em suma, as sementes de G. gardneriana têm baixa tolerância à dessecação e são sensíveis à refrigeração. Portanto, as sementes podem ser categorizadas como recalcitrantes e dormentes, uma combinação rara em termos de biologia de sementes.

Termos para indexação: enzimas antioxidantes, tolerância à dessecação, dormência física, poliaminas, germinação.
Journal of Seed Science, v.42, e202042001, 2020

http://dx.doi.org/10.1590/ 2317-1545v42222357
${ }^{*}$ Corresponding author
E-mail: neusasteiner@yahoo.com.br

Received: 4/6/2019. Accepted: $11 / 12 / 2019$.

${ }^{1}$ Laboratório de Fisiologia Vegetal, Departamento de Botânica, Universidade Federal de Santa Catarina, 88040-900 - Florianópolis, SC, Brasil. 


\section{INTRODUCTION}

Garcinia gardneriana (Planch. \& Triana) Zappi, known as bakupari, is a fruit species from the Clusiaceae family, which comprises 27 genera and 1.090 species (Stevens, 2007). The species is widely distributed in Brazil, occurring in the Amazon Rainforest, Caatinga, Central Brazilian Savanna and Atlantic Rainforest (Bittrich et al., 2015). It is a treesized plant with bright yellow fruits, containing one to three seeds. Although not domesticated, this species has high economic potential. Its morphological structure makes it very suitable to be used as an ornamental plant, its fruits can be consumed in natura, and its leaves are used in the traditional medicine to treat inflammations and infections (Cechinel Filho et al., 2000). Nevertheless, little is known about the seed germination process and the influence the environment has on it.

According to Bewley et al. (2013), seed germination begins with water absorption by the seed and ends with radicle protrusion, followed by the emergence of the embryonic axis through the surrounding structures. It is a physiological process that requires favorable environmental conditions of temperature, oxygen, humidity and light. However, when one or more environmental conditions are unfavorable, the germination does not occur. Furthermore, characteristics of the seed itself, or of the dispersion unit, may preclude germination, giving it a state of dormancy (Baskin and Baskin, 2014).

Physical dormancy is a state where the seed fails to germinate due to an impermeable structure, which prevents water from being absorbed (Baskin et al., 2000). Water content (WC) is correlated not only to seed germination but also to storage capacity, and this is directly associated with desiccation tolerance. In the 1970s, seeds were divided into two categories: orthodox and recalcitrant (Barbedo et al., 2013). According to this classification, desiccation-tolerant seeds (orthodox) survive desiccation to very low WC, below $0.1 \mathrm{~g} \mathrm{H}_{2} \mathrm{O} \cdot \mathrm{g}^{-1} \mathrm{dw}$, and withstand dry storage for long periods without a significant loss in viability (Marques et al., 2018). On the other hand, desiccation-sensitive seeds (recalcitrant)

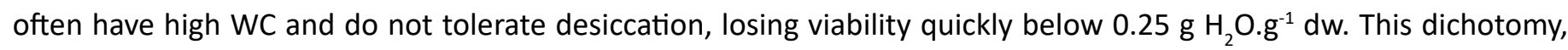
however, is now only appropriate for technological purposes, given the vast range of different behaviors that can be found within these two groups (Barbedo et al., 2013; Barbedo, 2018). For example, some species of the genus Garcinia were classified as being recalcitrant and dormant (Liu et al., 2005; Anegbeh et al., 2006). This combination in seeds is quite rare; in a survey of 886 species, only $1.4 \%$ were recalcitrant and had physical dormancy (Tweddle et al., 2003). Vázquez-Yanes and Orozco-Segovia (1993) state that very little is known about seeds that possess this combination, thus evidencing the importance of this species in studies about seed physiology behavior and viability.

Seed viability loss is dependent on a plethora of factors, among them genetics, mechanical damage, temperature and humidity, and seed WC (McDonald, 2004). Physiological deterioration can be seen as a result of the loss of membrane integrity, electrolyte leakage, reactive oxygen species (ROS) production, lipid peroxidation, changes in enzymatic activity etc. (Goel and Sheoran, 2003). The cellular damage caused by these free radicals is usually reduced or prevented by a protective mechanism involving peroxidase-scavenging enzymes, such as superoxide dismutase (SOD), catalase (CAT), glutathione reductase (GR) and ascorbate peroxidase (APX) (Goel et al., 2003; McDonald, 2004). Together with antioxidant enzymes, polyamines (PAs) have also been suggested to play a role in free radical scavenging (Drolet et al., 1986). According to Flores and Galston (1984), under water deficit, there is an accumulation of PAs that could act directly or indirectly as a free radical scavenger. Therefore, to study how these substances change and link this with seed physiological performance is of primary importance to understand the G. gardneriana seeds physiology.

Considering the current global concern on strategies for plant conservation of recalcitrant seeds and the lack of literature on the storage, dormancy-breaking and germination requirements of seeds from forest species, this study was developed. To the best of our knowledge, no studies have investigated that this species is indeed dormant and recalcitrant, neither was the relationship of this characteristic with the seed metabolism and dehydration. Thus, physical and physiological aspects such as the effects of the seed coat, desiccation and storage tolerance of G. gardneriana seeds were investigated. Additionally, PAs contents and enzyme activities were quantified over these effects, looking to correlate its contents to the physiological seed performance of this species. The results of this study improve 
the ecological understanding of seed physiology performance, and lead to practical applications in crops and seed conservation.

\section{MATERIAL AND METHODS}

\section{Fruit harvesting and seed processing}

Mature fruits of G. gardneriana were harvested from a population located in Içara, Santa Catarina. The seed processing consisted of the removal of the mucilaginous mesocarp by friction, followed by washing in water and drying in a paper towel. Seeds with visible mechanical damage or very small were discarded.

\section{Imbibition curve and effect of the seed coat on water uptake}

Intact (i.e., with seed coat) and decoated seeds were placed in germination boxes containing vermiculite substrate

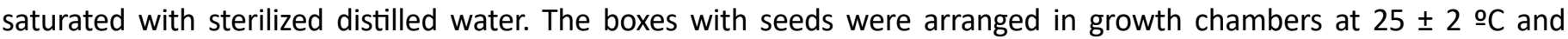
photoperiod of twelve hours $\left(142 \mu \mathrm{mol} . \mathrm{m}^{-2} . \mathrm{s}^{-1}\right)$. Seeds were weighed before imbibition, at two-hour-intervals for the first twelve hours, and at twenty-four-hour-intervals until $50 \%$ of seed germination. A seed was considered germinated when it produced radicle and epicotyl (normal seedling). The percentage of mass increment over time, as a function of initial seed mass, was calculated as $\%=\left[\frac{(M t-M i)}{M i}\right] * 100$, where $\mathrm{Mi}=$ initial fresh mass of the sample, and $\mathrm{Mt}=$ mass sample at the time of harvesting (Justo et al., 2007). To determine whether water was absorbed or retained in the seed coat, ten intact seeds and ten decoated seeds were imbibed in methylene blue solution for fifteen days (based on the imbibition curve), then cross-sectioned and evaluated in a stereo microscope for the absorption of the solution (Liu et al., 2005).

\section{Water content determination}

Seeds were dried at $105 \pm 3 \stackrel{\circ}{C}$ for $24 \mathrm{~h}$ (Brasil, 2009). Four replicates of five intact seeds were cut into small pieces, weighed initially and after the drying period. The WC was expressed on a dry weight basis $\left(\mathrm{g} \mathrm{H}_{2} \mathrm{O}_{\mathrm{g}} \mathrm{g}^{-1} \mathrm{dw}\right.$ ) (Black and Pritchard, 2002).

\section{Desiccation tolerance}

To evaluate desiccation tolerance, fresh seeds (FS) were dried in hermetically sealed containers using silica gel at room temperature (average of $27 \mathrm{O} C$ ). The seeds were desiccated for 5, 10, 15 and 20 days, using as reference the WC determined for FS. Silica gel was used in a ratio of 2:1 and was replaced every $24 \mathrm{~h}$ (Zhang and Tao, 1989). Every day seeds were weighed, and water loss was calculated according to Hong and Ellis (1996).

\section{Tetrazolium test}

Four replicates of eight seeds were used for all treatments. A longitudinal cut was made in the seed, and the embryos were immersed in 1\% 2,3,5-triphenyltetrazolium chloride solution at $30 \stackrel{\circ}{C}$ for two hours (Brasil, 2009). The embryos were classified as viable or unviable, according to Brasil (2009).

\section{Electrolyte leakage}

Electrolyte leakage was estimated according to Marcos-Filho et al. (1987). Four replicates of eight seeds were used. The seeds were weighed and imbibed in $100 \mathrm{~mL}$ beakers containing $50 \mathrm{~mL}$ deionized water and kept in a growth chamber at 25 ㅇ for different imbibition times $(2,4,6,8,10,12$ and $24 \mathrm{~h})$. After each imbibition period, the electrolyte leakage was evaluated using a conductivity sensor (SD201, Saiv A/S, Norway). The results were expressed in $\mu$ S. $\mathrm{cm}^{-1} \cdot \mathrm{g}^{-1}$. 
Germination and seedling evaluation

For the germination test, seeds were previously disinfested with $70 \%$ ethanol for one minute, and sodium hypochlorite solution $(2 \%, v / v)$ for five minutes. Germination counts were made daily. Germination criteria were the same used for the imbibition curve (normal seedling). The viability of the non-germinated seeds was verified through the tetrazolium test. At the end of the germination tests, the mean germination time (MGT) was calculated according to Edwards (1934).

\section{Storage tolerance}

Tolerance to storage was evaluated by storing intact $\mathrm{FS}$ at $25^{\circ} \mathrm{C}$ and $5{ }^{\circ} \mathrm{C}$ for ninety days. After the storage period, the seeds were submitted to the germination test, MGT and seedling evaluation, as described previously.

\section{Polyamines quantification}

For PAs determination, three samples $(200 \mathrm{mg}$ ) of embryos of fresh and desiccated seeds were ground in $1.6 \mathrm{~mL}$ of $5 \%(\mathrm{v} / \mathrm{v})$ perchloric acid. Free and conjugated PAs were extracted, dansylated and quantified, according to Steiner et al. (2007), with modifications. PAs concentration was determined using a fluorescence detector at $340 \mathrm{~nm}$ (excitation) and $510 \mathrm{~nm}$ (emission). Peak areas and retention times were measured by comparison with standard PAs: putrescine, spermidine and spermine. The 1,7-diaminoheptane (DAH) was used as the internal standard.

\section{Enzyme extraction and assays}

Three samples (300 mg) of embryos of fresh and desiccated seeds were homogenized on ice with $1 \mathrm{~mL}$ of $50 \mathrm{mM}$ potassium phosphate buffer ( $\mathrm{pH}$ 7.0) containing $1 \mathrm{mM}$ EDTA and 1\% polyvinylpyrrolidone (PVP). The homogenate was centrifuged at $15000 \mathrm{~g}$ for twenty minutes at $4{ }^{\circ} \mathrm{C}$. Protein content was determined according to Bradford (1976). The resulting supernatant was filtered and used for the enzyme assays. Superoxide dismutase (SOD; EC 1.15.1.1) activity was measured by monitoring the inhibition of photochemical reduction of NBT, according to Giannopolitis and Ries (1977). Catalase (CAT; EC 1.11.1.6) activity was determined by following the consumption of hydrogen peroxide $\left(\mathrm{H}_{2} \mathrm{O}_{2}\right)($ Peixoto et al., 1999). Ascorbate peroxidase (APX; EC 1.11.1.11) activity was determined by following the decrease in A290 (Koshiba, 1993). Glutathione reductase (GR; EC 1.6.4.2) activity was determined by following the oxidation of NADPH (Bailly and Kranner, 2011). SOD, CAT, APX and GR activities of each extract were measured three times, and the results correspond to the means \pm SD of the values obtained with three different extracts and three measurements per extract (i.e., nine measurements).

\section{Statistical procedures}

The design was completely randomized in all tests unless stated otherwise. Each treatment was composed of four replications of fourteen seeds each. Data normality was evaluated using the Shapiro-Wilk test and analyzed using an analysis of variance (ANOVA), followed by a Student-Newman-Keuls posthoc test $(p<0.05)$. Statistical procedures were carried out with R 3.4.4 programming environment ( $\mathrm{R}$ Core Team).

\section{RESULTS AND DISCUSSION}

Decoated seeds absorbed water slowly and started germinating twelve days after sowing (DAS) (Figure 1a). Removal of the seed coat resulted in a mass increment of $11 \%$ throughout the imbibition test. On the other hand, intact seeds showed a rapid increase in mass in the first hour, reaching $5 \%$ in only six hours of imbibition. However, after this point, water absorption plateaued; between 8 and $360 \mathrm{~h}$, there was a mass increase of only 1\%, thus showing that water absorption became nearly stable. Intact seeds failed to germinate by the end of the imbibition test. The imbibition test with methylene blue solution showed that only decoated seeds absorbed the solution (Figure 1b). 


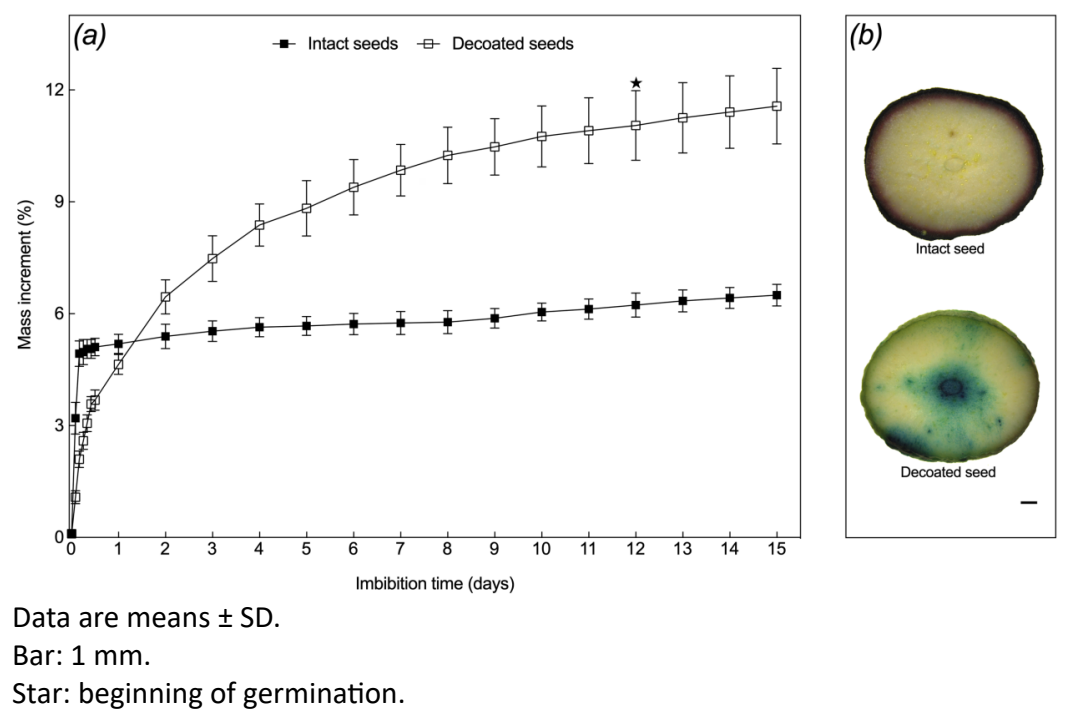

Figure 1. Imbibition curve of G. gardneriana seeds and the effects of the seed coat in water uptake. (a) Dynamics of increment on initial fresh mass in function of time (\%). Details of water uptake in the first $24 \mathrm{~h}$ indicated on the right lower corner. (b) Cross-section of seeds imbibed in methylene blue solution. Intact seed showing no absorption and decoated seed with visible absorption of the solution.

According to Hidayati et al. (2001), the increase in mass does not necessarily indicate that water has surpassed the seed coat; instead, it can be true that water was absorbed just on the seed coat itself. The data presented in this work corroborate with this statement since the seeds could not overcome the physical barrier imposed by the seed coat, resulting in the near stabilization of water absorption. Conversely, decoated seeds absorbed water slowly but throughout until seed germination occurred. According to Liu et al. (2005), this slow absorption rate is due to the seeds having a high initial WC. Nevertheless, $50 \%$ of the seeds germinated at the end of the test in a relatively short period. These results indicate that the seed coat of G. gardneriana confers physical dormancy on the seeds, which prevents water uptake and quick germination. In nature, these structures that preclude germination become permeable through the action of moist and dry heat, strong acids, coat piercing, or even by going through an animal gut (Vázquez-Yanes and Orozco-Segovia, 1993). This means that, in nature, G. gardneriana seeds could have different germination times, depending on the speed on which these factors act on the seed coat, which is a good strategy for germination and seedling establishment success on a wild ecosystem. In this sense, because the seed coat of $G$. gardneriana prevents germination, to propagate this species in practical application or experimental research, the removal of the seed coat is recommended to obtain more immediate and uniform germination.

The lifespan of recalcitrant seeds is significantly affected by temperature, humidity and the WC of the seeds (Marques et al., 2018). G. gardneriana FS were shed at a high WC (1.07 $\left.\mathrm{g} \mathrm{H}_{2} \mathrm{O}_{\mathrm{g}} \mathrm{g}^{-1} \mathrm{dw}\right)$, showed high viability (Figure 2b), the lowest electrolyte leakage rate (Figure $2 \mathrm{c}$ ) and fastest MGT and highest normal seedling production (Table 1). The seeds lost water at a rate of $4 \%$ per day until the end of the desiccation period (Figure 2a). Reduction in WC to $0.67 \mathrm{~g} \mathrm{H}_{2} \mathrm{O}^{-1} \mathrm{gdw}^{-1}$ had an adverse effect on the seeds; germination was reduced by $57 \%$ (Figure $2 \mathrm{~d}$ ). This discrepancy suggested that this was the critical WC for these seeds. Desiccating seeds to $0.43 \mathrm{~g} \mathrm{H}_{2} \mathrm{O}^{-1} \mathrm{gdw}^{-1}$ was very detrimental. All tests indicate that seeds do not tolerate this WC loss; only $8 \%$ of seeds germinated (Figure $2 \mathrm{~d}$ ). Desiccation below $0.25 \mathrm{~g} \mathrm{H}_{2} \mathrm{O}^{-\mathrm{g}^{-1}} \mathrm{dw}$ was lethal. Our results, together with the fact that a few Garcinia species were classified as having recalcitrant seeds (Liu et al., 2005; Malik et al., 2005), suggest that G. gardneriana also has this behavior, since its seeds are highly sensitive to desiccation.

Seeds of $G$. gardneriana also showed to be very sensitive to storage and chilling. FS were capable of retaining viability for ninety days at $25{ }^{\circ} \mathrm{C}$ to the same level as seeds desiccated to $0.67 \mathrm{~g} \mathrm{H}_{2} \mathrm{O}^{-1} \mathrm{~g}^{-1}$ (Table 2). One possible explanation for this may be that these seeds lost water slowly during storage due to the high temperature. Therefore, these seeds may also have 
suffered the same damages as the desiccated seeds, which caused the loss of viability. Seeds stored for ninety days at 5 으 did not germinate (Figure $2 \mathrm{~d}$ ), thus indicating that this species is very sensitive to chilling.
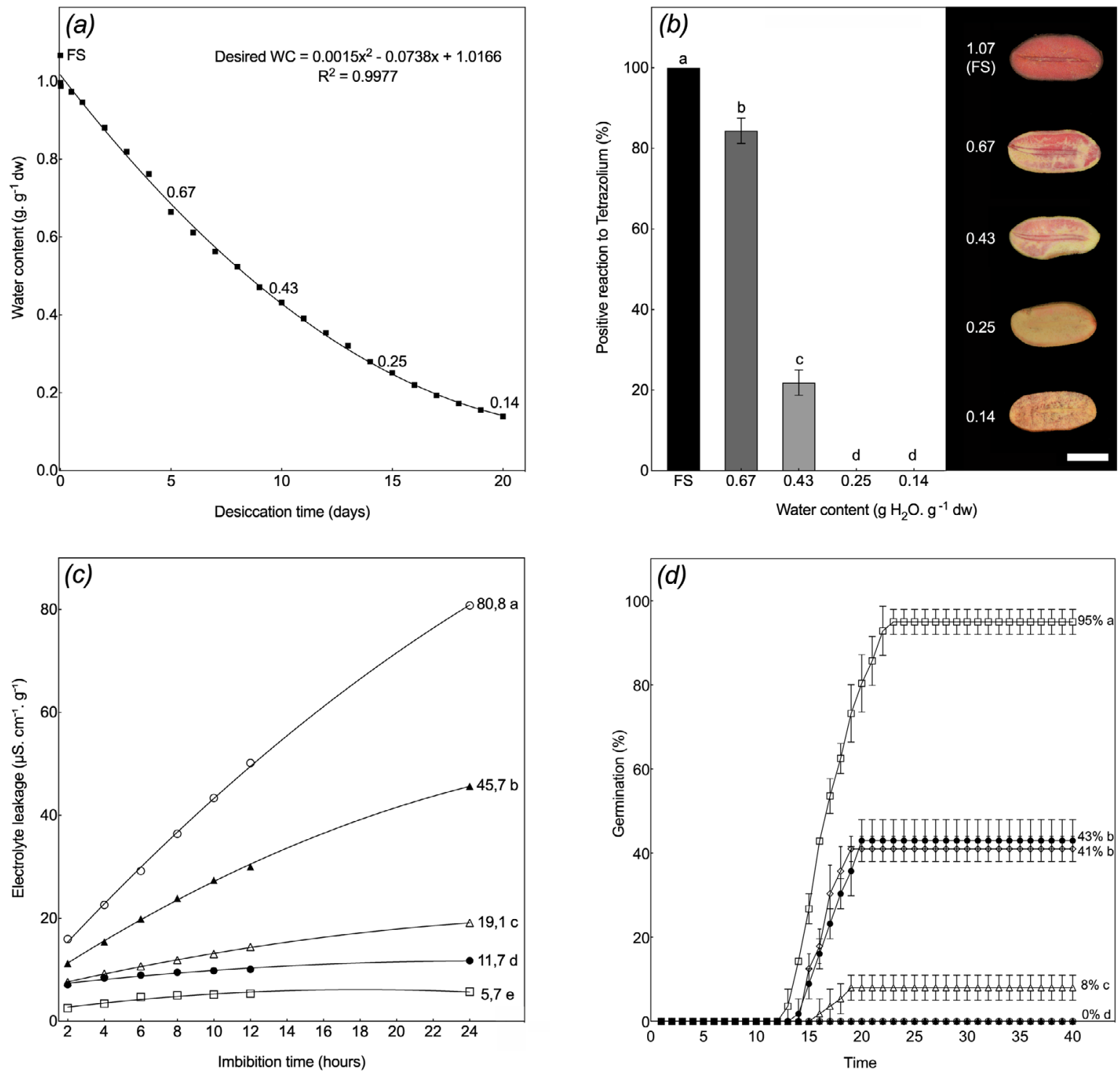

$$
\begin{aligned}
& \square \text { FS: } y=-0.0362 x^{2}+3.9176 x+7.7214 R^{2}=0.999 \\
& \rightarrow 0.67: y=-0.0302 x^{2}+2.3448 x+6.7461 R^{2}=0.999 \\
& \triangle 0.43: y=-0.0122 x^{2}+0.8383 x+6.0319 R^{2}=0.999 \\
& \rightarrow 0.25: y=-0.0082 x^{2}+0.4092 x+6.6182 R^{2}=0.976 \\
& -0.13: y=-0.0133 x^{2}+0.4801 x+1.8416 R^{2}=0.945
\end{aligned}
$$

Abbreviation: $\mathrm{FS}=$ fresh seeds.

Means followed by the same letters do not show significant differences according to the SNK test $(p<0.05)$.

Bar: $1 \mathrm{~cm}$.

Figure 2. Physiological performance of the seeds due to desiccation. (a) Water content of G. gardneriana seeds as a function of desiccation time (days). (b) Tetrazolium test with G. gardneriana seeds of different WC. On the right, Percentage of positive reaction of $G$. gardneriana seeds to $1 \%$ 2,3,5-triphenyltetrazolium chloride (Tetrazolium). $C V=9.58 \%$. On the left, the effect of desiccation on the Tetrazolium salt reaction with the embryo tissues. Seeds that reacted positively to tetrazolium: $\mathrm{FS}, 0.67$ and $0.43 \mathrm{~g} \mathrm{H}_{2} \mathrm{O} . \mathrm{g}^{-1} \mathrm{dw}$. Seeds that did not react to tetrazolium: 0.25 and $0.14 \mathrm{~g} \mathrm{H}_{2} \mathrm{O} . \mathrm{g}^{-1} \mathrm{dw}$. (c) Effects of desiccation on electrolyte leakage $\left(\mu \mathrm{S} . \mathrm{cm}^{-1} \cdot \mathrm{g}^{-1}\right)$ in $\mathrm{G}$. gardneriana seeds. $\mathrm{CV}=11.73 \%$. (d) Germination curve of $\mathrm{G}$. gardneriana seeds with different WC ( $\mathrm{g} \mathrm{H}_{2} \mathrm{O}^{-1} \mathrm{~g}^{-1} \mathrm{dw}$ ). $\mathrm{CV}=6.29 \%$. 
Table 1. Mean germination time (MGT) and germination of G. gardneriana seeds with different water content.

\begin{tabular}{ccccc}
\hline \multirow{2}{*}{ Treatment } & MGT (days) & Normal seedling & Abnormal seedling & Dead seed \\
\cline { 3 - 4 } & & $95 \pm 3 \mathrm{a}$ & $5 \pm 3 \mathrm{c}$ & $0 \mathrm{~d}$ \\
\hline Fresh seeds & $18 \pm 0.3 \mathrm{c}$ & $43 \pm 5 \mathrm{~b}$ & $39 \pm 4 \mathrm{a}$ & $19 \pm 3 \mathrm{c}$ \\
$0.67 \mathrm{~g} \mathrm{H}_{2} \mathrm{O} \cdot \mathrm{g}^{-1} \mathrm{dw}$ & $22 \pm 0.2 \mathrm{~b}$ & $8 \pm 3 \mathrm{c}$ & $14 \mathrm{~b}$ & $78 \mathrm{~b}$ \\
$0.43 \mathrm{~g} \mathrm{H}_{2} \mathrm{O} . \mathrm{g}^{-1} \mathrm{dw}$ & $24 \pm 1 \mathrm{a}$ & $0 \mathrm{~d}$ & $0 \mathrm{~d}$ & $100 \mathrm{a}$ \\
$0.25 \mathrm{~g} \mathrm{H}_{2} \mathrm{O} . \mathrm{g}^{-1} \mathrm{dw}$ & $0 \mathrm{~d}$ & $0 \mathrm{~d}$ & $0 \mathrm{~d}$ & $100 \mathrm{a}$ \\
$0.14 \mathrm{~g} \mathrm{H}_{2} \mathrm{O} . \mathrm{g}^{-1} \mathrm{dw}$ & $0 \mathrm{~d}$ & & & \\
\hline
\end{tabular}

Data are mean \pm SD.

Means followed by the same letters do not show significant differences according to the SNK test $(p<0.05)$.

Table 2. Mean germination time (MGT) and germination of G. gardneriana seeds with different storage conditions.

\begin{tabular}{ccccc}
\hline \multirow{2}{*}{ Treatment } & MGT (days) & & Germination (\%) \\
\cline { 2 - 5 } & & Normal seedlings & Abnormal seedlings & Dead seeds \\
\hline Fresh seeds & $18 \pm 0.3 \mathrm{~b}$ & $95 \pm 3 \mathrm{a}$ & $5 \pm 3 \mathrm{~b}$ & $0 \mathrm{c}$ \\
Stored at 25 $9 \mathrm{C}$ & $21 \pm 2 \mathrm{a}$ & $41 \pm 3 \mathrm{~b}$ & $39 \pm 4 \mathrm{a}$ & $20 \pm 3 \mathrm{~b}$ \\
Stored at 5 $\circ \mathrm{C}$ & $0 \mathrm{c}$ & $0 \mathrm{c}$ & $0 \mathrm{c}$ & $100 \mathrm{a}$ \\
\hline
\end{tabular}

Data are mean \pm SD.

Means followed by the same letters do not show significant differences according to the SNK test $(p<0.05)$.

According to Pammenter and Berjak (1999), the loss of germination capacity is associated with a lack of mechanisms related to the acquisition of tolerance to desiccation. Among these mechanisms are protective proteins and metabolites (LEAs, antioxidant enzymes, sugars, polyamines), hormones (ABA accumulation, GA reduction), transcription factors and physiological processes (DNA and protein repair, cytoplasm vitrification, membrane stabilization) (Marques et al., 2018).

However, maintaining this machinery comes with a high cost; hence, several species have lost tolerance to desiccation or storage, depending on the environment they are found. Seed longevity, desiccation tolerance and dormancy are very important traits for seeds that are found in a heterogeneous environment because they enhance the ability to survive in adverse conditions (Marques et al., 2018). On the other hand, most species that evolved in relatively stable environments, such as ecosystems with typical rainy seasons, do not need these mechanisms since the environment they are found favors faster germination (Souza et al., 2015).

Barbedo et al. (2013) define seed longevity as an interaction among genetic information, reduction factors (WC, temperature, degree of maturation at shedding) and improvement factors (dormancy). These factors seem to be established in a dynamic way, varying in intensity based on what is more advantageous to the adaptation of the species. Therefore, according to their model, the paradoxical combination of physical dormancy and desiccation sensitivity in G. gardneriana can be explained.

To shed light on the metabolism of these seeds, antioxidant enzymes and polyamines as biomolecules involved in the seed physiology performance were also studied. G. gardneriana FS showed high activities of SOD, CAT, APX and GR (Figure 3), indicating that the antioxidant system was operating efficiently in the removal of ROS, since seeds were the most viable. Several studies have investigated the relationship between loss of viability and the oxidative stress in recalcitrant seeds (Li and Sun, 1999; Varghese and Naithani, 2002; Cheng and Song, 2008).

ROS play an important role in seed physiology, acting as signaling of cellular pathways, but also as toxic products that accumulate under stress conditions, such as desiccation (Jeevan Kumar et al., 2015). For the successful destruction of superoxide radicals and $\mathrm{H}_{2} \mathrm{O}_{2}$, scavenging enzymes need to work together. Superoxide radicals produced by biochemical reactions in plant cells are rapidly converted to $\mathrm{H}_{2} \mathrm{O}_{2}$ by SOD, and then CAT converts $\mathrm{H}_{2} \mathrm{O}_{2}$ to $\mathrm{H}_{2} \mathrm{O}$ and oxygen (Cheng and 
Song, 2008). APX and GR are closely correlated in the ascorbate-glutathione cycle and are known for scavenging $\mathrm{H}_{2} \mathrm{O}_{2}$ directly and indirectly (Bailly, 2004).

Comparatively to G. gardneriana FS, desiccation resulted in a decrease in SOD and APX activity (Figures 3a and 3b), with no difference among the desiccated treatments. CAT activity showed an inverse pattern, increasing significantly (Figure 3c). GR activity did not differ among fresh and desiccated seeds (Figure 3d). According to Bailly et al. (2001), loss of SOD and APX activity leads to an accumulation of ROS, which can be compensated by the increase in CAT activity, who also scavenges $\mathrm{H}_{2} \mathrm{O}_{2}$. This seems to be the case for $\mathrm{G}$. gardneriana seeds, where CAT activity increased in desiccated seeds, as a result of impairment of SOD and APX activities. However, it was not enough to keep the seeds viable. Even though GR is known for contributing to the regeneration of ascorbate and participates indirectly in scavenging of $\mathrm{H}_{2} \mathrm{O}_{2}$ (Tommasi et al., 2001), in G. gardneriana desiccated seeds, this enzyme does not seem to have played a significant role, because APX activity decreased and viability decreased as well. The results indicate that the significant decreases in SOD and APX may be correlated to the desiccation sensitivity of the seeds. These results corroborate with the study of Li and Sun (1999), who found a correlation between the rapid decrease in enzymatic protection by SOD and APX against
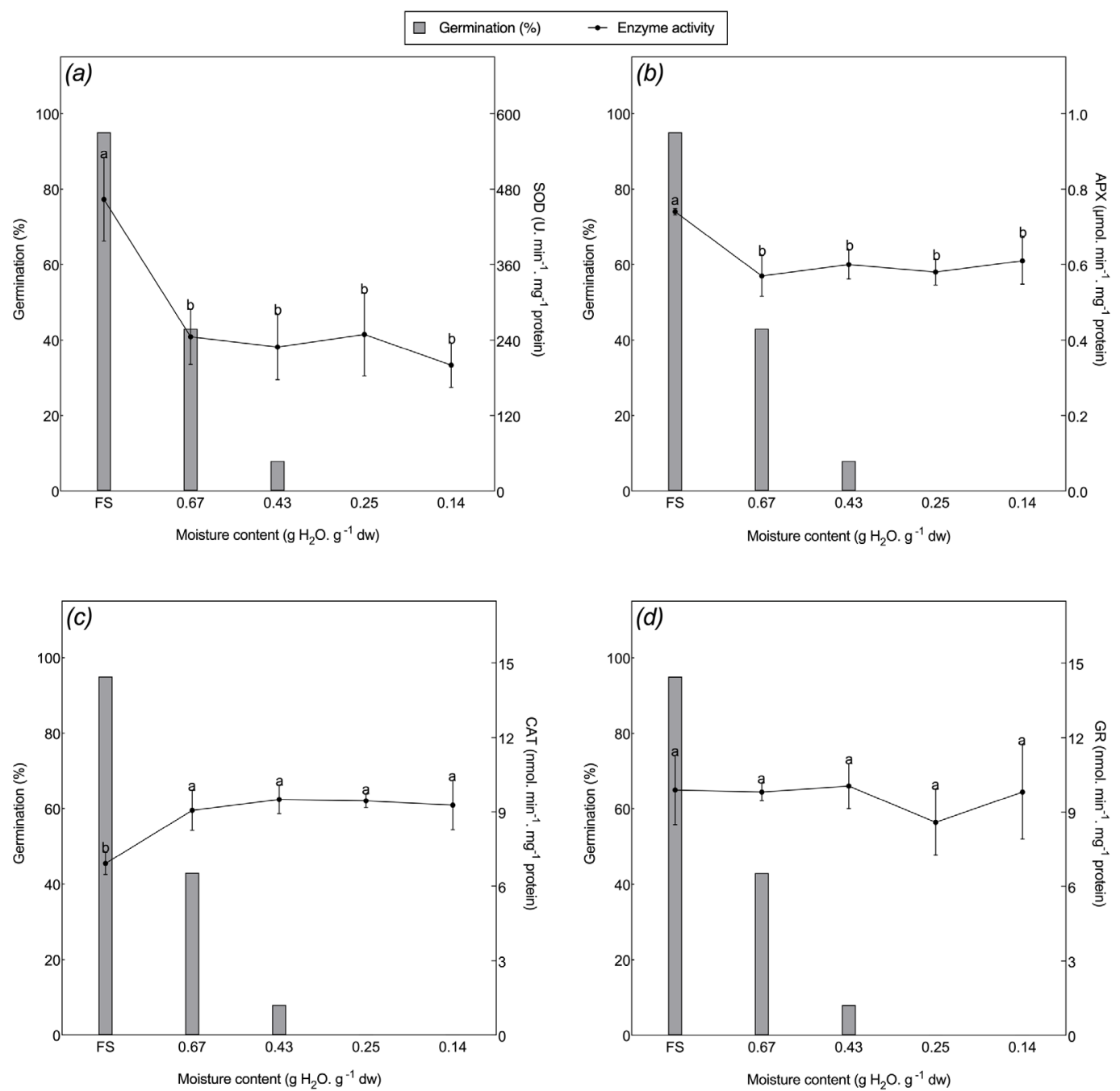

Abbreviations: $\mathrm{APX}=$ ascorbate peroxidase; $\mathrm{CAT}=$ catalase; $\mathrm{GR}=$ glutathione reductase; $\mathrm{SOD}=$ superoxide dismutase; $\mathrm{FS}=$ fresh seeds. CV SOD: $19.5 \%$; CV APX: 7\%; CV CAT: $7.5 \%$; CV GR: $13 \%$.

Bar: germination percentage.

Enzyme activity means followed by the same letters do not show significant difference according to the SNK test $(p<0.05)$.

Figure 3. Effects of desiccation of G. gardneriana seeds on SOD (a), APX (b), CAT (c) and GR (d) activities. 
oxidative stress and desiccation sensitivity of cocoa (Theobroma cacao) axes and cotyledons. Conversely, Varghese and Naithani (2002) found that SOD increased markedly with desiccation of neem (Azadirachta indica A. Juss) seeds; however, an impairment in CAT leads to ROS production, thus resulting ultimately in the loss of viability. This contrast in enzyme activities serves as evidence that an entirely functional and cooperating antioxidant system is required to retain seed viability.

Together with antioxidant enzymes, the role of PAs regarding stress tolerance has been widely investigated. One of the many roles PAs play is in the scavenging of ROS by influencing the activity of antioxidant enzymes (Li et al., 2015b; Juzoń et al., 2017). In general, plants are characterized for possessing a high capacity of increasing endogenous contents of PAs in response to stress (Juzoń et al., 2017). In G. gardneriana seeds, free PAs content was higher in FS for PUT and SPD (Figures 4a and 4b). After desiccation, the content of these two PAs significantly decreased. Conversely, SPM content increased when seeds were desiccated to $0.67 \mathrm{~g} \mathrm{H}_{2} \mathrm{O} . \mathrm{g}^{-1} \mathrm{dw}$, but decreased when seeds were desiccated further (Figure 4c). These results corroborate with the fact that PUT is used for the synthesis of SPD, which is then converted into SPM (Liu et al., 2015).
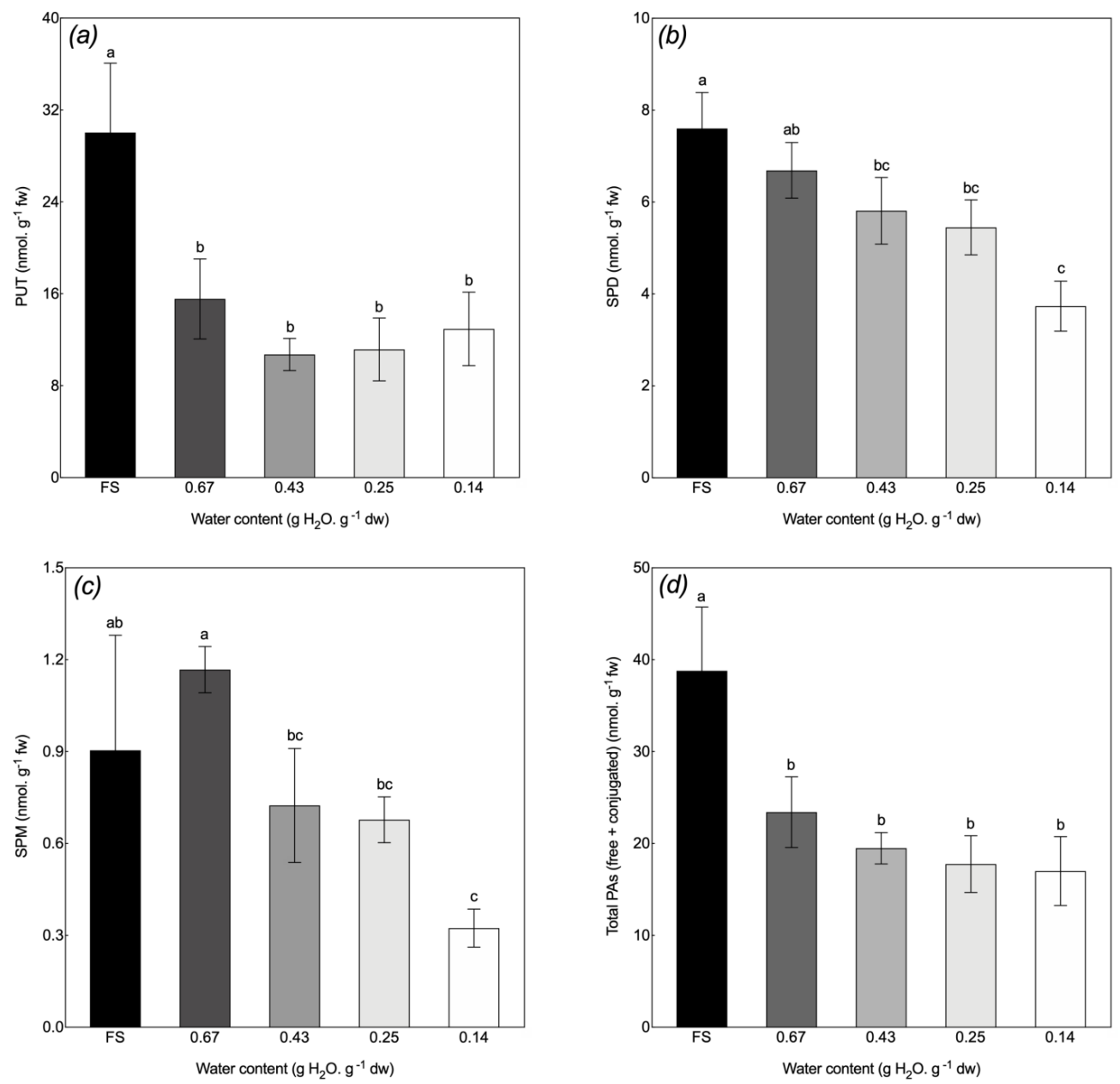

Abbreviations: $\mathrm{PAs}=$ polyamines; $\mathrm{PUT}=$ putrescine; $\mathrm{SPD}=$ spermidine; $\mathrm{SPM}=$ spermine; $\mathrm{FS}$ = fresh seeds. CV free PUT: $23 \%$; CV free SPD: $11 \%$; CV free SPM: $26 \%$; CV Total PAs: $18 \%$.

Enzyme activity means followed by the same letters indicate a significant difference between treatments at $p<0.05$ according to the SNK test.

Figure 4. Endogenous contents ( $n$ mol. $\mathrm{g}^{-1} \mathrm{fw}$ ) of free polyamines: PUT (a), SPD (b), SPM (c) and total PAs (free + conjugated). (d) In mature seeds of $G$. gardneriana under different data are means of three replicates \pm SD. 
It seems that for G. gardneriana, PUT and SPD was converted to SPM in an attempt to stop seed deterioration caused by desiccation. SPM is involved in membrane stability and osmotic adjustment, both important processes during the desiccation phase of seeds (Li et al., 2015b). Furthermore, several studies found that the exogenous application of SPM increased drought tolerance by elevating the activity of antioxidant enzymes, such as SOD and CAT, which then resulted in a decrease in ROS activity (Shi et al., 2010; Li et al., 2015a), indicating the effective role of this PA against abiotic stress. These findings corroborate with the SPM contents found for G. gardneriana seeds (Figure 4c).

Desiccation to $0.67 \mathrm{~g} \mathrm{H}_{2} \mathrm{O} . \mathrm{g}^{-1} \mathrm{dw}$ resulted in an increase in SPM content; however, the action of SPM in membrane stabilization and increasing the activity of antioxidant enzymes was not enough to prevent seed deterioration and, thus, the seed viability was lost. The high content of total PAs (Figure 4D) for G. gardneriana FS, and the markedly decrease after desiccation and germination indicate a positive correlation in seed viability and PAs in this species.

These data are considered to be a starting point for understanding and establishing the main biological criteria for better management of this species seeds in its wild ecosystem, considering its economic, medicinal and ecological potential.

\section{CONCLUSIONS}

The results indicate that the seed coat in this species precludes imbibition and, consequently, germination. The seeds do not tolerate desiccation and storage; therefore, this species is categorized as having highly recalcitrant seeds.

\section{ACKNOWLEDGMENTS}

The authors thank the staff of the Plant Physiology Laboratory and Plant Developmental Physiology and Genetics Laboratory (LFDGV) of the Universidade Federal de Santa Catarina, Brazil.

\section{REFERENCES}

ANEGBEH, P.; IRUKA, C.; NIKIRIKA, C. Enhancing germination of bitter cola (Garcinia kola) Heckel: prospects for agroforestry farmers in the Niger Delta. Scientia Africana, v.5, n.1, p.38-44, 2006. www.worldagroforestry.org/downloads/Publications/PDFS/ja06109.doc

BAILLY, C. Active oxygen species and antioxidants in seed biology. Seed Science Research, v.14, n.2, p.93-107, 2004. https://doi. org/10.1079/SSR2004159

BAILLY, C.; AUDIGIER, C.; LADONNE, F.; WAGNER, M.H.; COSTE, F.; CORBINEAU, F.; CÔME, D. Changes in oligosaccharide content and antioxidant enzyme activities in developing bean seeds as related to acquisition of drying tolerance and seed quality. Journal of Experimental Botany, v.52, n.357, p.701-708, 2001. https://doi.org/10.1093/jexbot/52.357.701

BAILLY, C.; KRANNER, I. Analyses of reactive oxygen species and antioxidants in relation to seed longevity and germination. Methods in Molecular Biology, v.773, p.343-367, 2011. https://doi.org/10.1007/978-1-61779-231-1_20

BARBEDO, C.J.; CENTENO, D.C.; FIGUEIREDO-RIBEIRO, R.C.L. Do recalcitrant seeds really exist? Hoehnea, v.40, n.4, p.583-593, 2013. https://www.scielo.br/pdf/hoehnea/v40n4/01.pdf

BARBEDO, C.J. A new approach towards the so-called recalcitrant seeds. Journal of Seed Science, v.40, n.3, p.221-236, 2018. http:// dx.doi.org/10.1590/2317-1545v40n3207201

BASKIN, C.C.; BASKIN, J.M. Seeds: ecology, biogeography and evolution of dormancy and germination. Elsevier, 2014. 1600p.

BASKIN, J.M.; BASKIN, C.C.; LI, X. Taxonomy, anatomy and evolution of physical dormancy in seeds. Plant Species Biology, v.15, n.2, p.139-152, 2000. https://esj-journals.onlinelibrary.wiley.com/doi/epdf/10.1046/j.1442-1984.2000.00034.x

BEWLEY, D.J.; BRADFORD, K.; HILHORST, H. Seeds: physiology of development, germination and dormancy. Springer Science and Business Media, 2013.

BITTRICH, V.; TRAD, R.J.; CABRAL, F.N.; NASCIMENTO-JR, J.E.; SOUZA, V.C. Clusiaceae in list of species of Brazilian flora. Rio de Janeiro's Botanical Garden. Available on <http://floradobrasil.jbrj.gov.br/jabot/floradobrasil/FB6853>. Accessed on March $18^{\text {th }}, 2019$. 
BLACK, M.; PRITCHARD, H.W. Desiccation and survival in plants: drying without dying. CABI Publishing, 2002. 412p.

BRADFORD, M.M. A rapid and sensitive method for the quantitation of microgram quantities of protein utilizing the principle of protein-dye binding. Analytical Biochemistry, v.72, n.1-2, p.248-254, 1976. https://doi.org/10.1016/0003-2697(76)90527-3

BRASIL. Ministério da Agricultura, Pecuária e Abastecimento. Regras para análise de sementes. Ministério da Agricultura, Pecuária e Abastecimento. Secretaria de Defesa Agropecuária. Brasília: MAPA/ACS, 2009. 395p. http:// www.agricultura.gov.br/arq_editor/ file/2946_regras_analise__sementes.pdf

CECHINEL-FILHO, V.; SILVA, K.L.; SOUZA, M.M.; OLIVEIRA, A.E.; YUNES, R.A.; GUIMARÃES, C.L.; VERDI, L.G.; SIMIONATTO, E.L.; DELLE MONACHE, F. I3-Naringenin-II8-4'-OMe-eriodictyol: a new potential analgesie agent isolated from Rheedia gardneriana leaves. Zeitschrift für Naturforschung C, v.55, n.9-10, p.820-823, 2000. https://doi.org/10.1515/znc-2000-9-1024

CHENG, H.Y.; SONG, S.Q. Possible involvement of reactive oxygen species scavenging enzymes in desiccation sensitivity of Antiaris toxicaria seeds and axes. Journal of Integrative Plant Biology, v.50, n.12, p.1549-1556, 2008. https://onlinelibrary.wiley.com/doi/ epdf/10.1111/j.1744-7909.2008.00723.x

DROLET, G.; DUMBROFF, E.; LEGGE, R.; THOMPSON, J. Radical scavenging properties of polyamines. Phytochemistry, v.25, n.2, p.367-371, 1986. https://doi.org/10.1016/S0031-9422(00)85482-5

EDWARDS, T.I. Relations of germinating soybeans to temperature and length of incubation time. Plant Physiology, v.9, n.1, p.1, 1934. https://www.ncbi.nlm.nih.gov/pmc/articles/PMC439825/pdf/plntphys00319-0008.pdf

FLORES, H.E.; GALSTON, A.W. Osmotic stress-induced polyamine accumulation in cereal leaves: I. Physiological parameters of the response. Plant Physiology, v.75, p.102-109, 1984. http://www.plantphysiol.org/content/plantphysiol/75/1/102.full.pdf

GIANNOPOLITIS, C.N.; RIES, S.K. Superoxide dismutases: I. Occurrence in higher plants. Plant Physiology, v.59, p.309-314, 1977. http://www.plantphysiol.org/content/plantphysiol/59/2/309.full.pdf

GOEL, A.; GOEL, A.K.; SHEORAN, I.S. Changes in oxidative stress enzymes during artificial ageing in cotton (Gossypium hirsutum L.) seeds. Journal of Plant Physiology, v.160, n.9, p.1093-1100, 2003. https://doi.org/10.1078/0176-1617-00881

GOEL, A.; SHEORAN, I. Lipid peroxidation and peroxide-scavenging enzymes in cotton seeds under natural ageing. Biologia Plantarum, v.46, n.3, p.429-434, 2003. https://doi.org/10.1023/A:1024398724076

HIDAYATI, S.N.; BASKIN, J.M.; BASKIN, C.C. Dormancy-breaking and germination requirements for seeds of Symphoricarpos orbiculatus (Caprifoliaceae). American Journal of Botany, v.88, n.8, p.1444-1451, 2001. https://bsapubs.onlinelibrary.wiley.com/ doi/epdf/10.2307/3558452

HONG, T.; ELLIS, R.H. A protocol to determine seed storage behaviour. Bioversity International, 1996.

JEEVAN KUMAR, S.; RAJENDRA PRASAD, S.; BANERJEE, R.; THAMMINENI, C. Seed birth to death: dual functions of reactive oxygen species in seed physiology. Annals of Botany, v.116, n.4, p.663-668, 2015. https://doi.org/10.1093/aob/mcv098

JUSTO, C.F.; ALVARENGA, A.A.D.; NERY, F.C.; DELU-FILHO, N. Composição química, curva de embebição e efeito da temperatura sobre a germinação de sementes de Eugenia pyriformis Camb. (Myrtaceae). Revista Brasileira Biociências, v.5, supl.2, p.510-512, 2007. http://www.ufrgs.br/seerbio/ojs/index.php/rbb/article/view/457/402

JUZOŃ, K.; CZYCZYŁO-MYSZA, I.; MARCIŃSKA, I.; DZIURKA, M.; WALIGÓRSKI, P.; SKRZYPEK, E. Polyamines in yellow lupin (Lupinus luteus L.) tolerance to soil drought. Acta Physiologiae Plantarum, v.39, n.202, 2017. https://link.springer.com/content/ pdf/10.1007\%2Fs11738-017-2500-z.pdf

KOSHIBA, T. Cytosolic ascorbate peroxidase in seedlings and leaves of maize (Zea mays). Plant and Cell Physiology, v.34, n.5, p.713721, 1993. https://doi.org/10.1093/oxfordjournals.pcp.a078474

LI, C.; SUN, W.Q. Desiccation sensitivity and activities of free radical-scavenging enzymes in recalcitrant Theobroma cacao seeds. Seed Science Research, v.9, n.3, p.209-217, 1999. https://doi.org/10.1017/S0960258599000215

LI, Z.; JING, W.; PENG, Y.; ZHANG, X.Q.; MA, X.; HUANG, L.K.; YAN, Y.H. Spermine alleviates drought stress in white clover with different resistance by influencing carbohydrate metabolism and dehydrins synthesis. PLoS One, v.10, n.4, 2015a. https://doi. org/10.1371/journal.pone.0120708 
LI, Z.; ZHANG, Y.; PENG, D.; WANG, X.; PENG, Y.; HE, X.; ZHANG, X.; MA, X.; HUANG, L.; YAN, Y. Polyamine regulates tolerance to water stress in leaves of white clover associated with antioxidant defense and dehydrin genes via involvement in calcium messenger system and hydrogen peroxide signaling. Frontiers in Physiology, v.6, n.280, 2015b. https://doi.org/10.3389/fphys.2015.00280

LIU, J.H.; WANG, W.; WU, H.; GONG, X.; MORIGUCHI, T. Polyamines function in stress tolerance: from synthesis to regulation. Frontiers in Plant Science, v.6, n.827, 2015. https://doi.org/10.3389/fpls.2015.00827

LIU, Y.; QIU, Y.P.; ZHANG, L.; CHEN, J. Dormancy breaking and storage behavior of Garcinia cowa Roxb. (Guttiferae) seeds: implications for ecological function and germplasm conservation. Journal of Integrative Plant Biology, v.47, n.1, p.38-49, 2005. https://doi. org/10.1111/j.1744-7909.2005.00010.x

MALIK, S.; CHAUDHURY, R.; ABRAHAM, Z. Desiccation-freezing sensitivity and longevity in seeds of Garcinia indica, G. cambogia and G. xanthochymus. Seed Science and Technology, v.33, n.3, p.723-732, 2005. https://doi.org/10.15258/sst.2005.33.3.20

MARCOS-FILHO, J.; CÍCERO, S.M.; SILVA, W.D. Seed quality evaluation. FEALQ Piracicaba, 1987.

MARQUES, A.; BUIJS, G.; LIGTERINK, W.; HILHORST, H. Evolutionary ecophysiology of seed desiccation sensitivity. Functional Plant Biology, v.45, n.11, p.1083-1095, 2018. https://doi.org/10.1071/FP18022

MCDONALD, M.B. Orthodox seed deterioration and its repair. In: BENECH-ARNOLD, R.; SANCHEZ, R. (ed.). Handbook of seed physiology: applications to agriculture. CRC Press, 2004. p.273-296.

PAMMENTER, N.; BERJAK, P. A review of recalcitrant seed physiology in relation to desiccation-tolerance mechanisms. Seed Science Research, v.9, n.1, p.13-37, 1999. https://doi.org/10.1017/S0960258599000033

PEIXOTO, P.H.P.; CAMBRAIA, J.; SANT'ANNA, R.; MOSQUIM, P.R.; MOREIRA, M.A. Aluminum effects on lipid peroxidation and on the activities of enzymes of oxidative metabolism in sorghum. Revista Brasileira de Fisiologia Vegetal, v.11, n.3, p.137-143, 1999. https://studylib.net/doc/13838404/aluminum-effects-on-lipid-peroxidation-and-metabolism-in-...

SHI, J.; FU, X.Z.; PENG, T.; HUANG, X.S.; FAN, Q.J.; LIU, J.H. Spermine pretreatment confers dehydration tolerance of citrus in vitro plants via modulation of antioxidative capacity and stomatal response. Tree Physiology, v.30, n.7, p.914-922, 2010. https://doi. org/10.1093/treephys/tpq030

SOUZA, T.V.; TORRES, I.C.; STEINER, N.; PAULILO, M.T.S. Seed dormancy in tree species of the Tropical Brazilian Atlantic Forest and its relationships with seed traits and environmental conditions. Brazilian Journal of Botany, v.38, n.2, p.243-264, 2015. https://doi. org/10.1007/s40415-014-0129-3

STEINER, N.; SANTA-CATARINA, C.; SILVEIRA, V.; FLOH, E.I.; GUERRA, M.P. Polyamine effects on growth and endogenous hormones levels in Araucaria angustifolia embryogenic cultures. Plant Cell, Tissue and Organ Culture, v.89, n.1, p.55-62, 2007. https://doi. org/10.1007/s11240-007-9216-5

STEVENS, P.F. Flowering plants - eudicots. In: KUBITZKI, K. (ed.). The Families and Genera of Vascular Plants. Springer, 2007. p.48-66.

TOMMASI, F.; PACIOLLA, C.; PINTO, M.C.; GARA, L.D. A comparative study of glutathione and ascorbate metabolism during germination of Pinus pinea L. seeds. Journal of Experimental Botany, v.52, n.361, p.1647-1654, 2001. https://doi.org/10.1093/ jexbot/52.361.1647

TWEDDLE, J.C.; DICKIE, J.B.; BASKIN, C.C.; BASKIN, J.M. Ecological aspects of seed desiccation sensitivity. Journal of Ecology, v.91, n.2, p.294-304, 2003. https://doi.org/10.1046/j.1365-2745.2003.00760.x

VARGHESE, B.; NAITHANI, S. Desiccation-induced changes in lipid peroxidation, superoxide level and antioxidant enzymes activity in neem (Azadirachta indica A. Juss) seeds. Acta Physiologiae Plantarum, v.24, n.1, p.79-87, 2002. https://doi.org/10.1007/s11738002-0025-5

VÁZQUEZ-YANES, C.; OROZCO-SEGOVIA, A. Patterns of seed longevity and germination in the tropical rainforest. Annual Review of Ecology and Systematics, v.24, p.69-87, 1993. https://doi.org/10.1146/annurev.es.24.110193.000441

ZHANG, X.; TAO, K. Silica gel seed drying for germplasm conservation: practical guidelines. Plant Genetic Resources Newsletter, n.75/76, p.1-5, 1989. https://www.bioversityinternational.org/fileadmin/_migrated/uploads/tx_news/Plant_Genetic_Resources_Newsletter_ No_75_76.pdf\#page=5 